2. Tor (Receiving organization)

2. To: (Receiving organization)

Distribution

5. Proj./Prog./Dept./Div.:

$\mathrm{N} 4 \mathrm{H} 3 \mathrm{E} /$ Characterization

Project Engineering

8. originator Remarks:

This Test Plan is submitted for review and approval.

This Test Plan is submitted for review and approval.

3. From: coriginating Organi
Engineering Testing
Laboratory (8C921)
6. Design Authority/ Design A
Engr:
G.P. Janicek (Design
Authority)

4. Related EOT No.:

11. Receiver Remarks: 11A. Design Baseline Document? [] Yes [X] No

\begin{tabular}{c} 
9. Equip./Component No.: \\
N/A \\
\hline 10. System/Bldg./Facility: \\
N/A
\end{tabular}

$\mathrm{N} / \mathrm{A}$

12. Major Assm. Dwg. No.:

$N / A$

13. Permit/Permit Application No.: $N / A$

14. Required Response Date:

ASAP



BD-7400-172-2 (05/96) GEF097 


\section{TESTING TO EXPAND THE ROTARY-MODE CORE SAMPLING SYSTEM OPERATING ENVELOPE}

Keith S. Witwer

Numatec Hanford Co., Richland, WA 99352

U.S. Department of Energy Contract DE-AC06-87RL10930
EDT/ECN: 601048
UC: 2070
Org Code: 8C921
Charge Code: $\mathrm{N} 4 \mathrm{H} 3 \mathrm{E}$
B\&R Code: EW3120074
Total Pages: 18

Key Words: RMCSS, Core Sampling, Rotary Bit

Abstract: This plan describes the testing parameters to be used to expand the current Rotary Mode Core Sampling Operating Envelope.

TRADEMARK DISCLAIMER. Reference herein to any specific comercial product, process, or service by trade name, trademark, manufacturer, or otherwise, does not necessarily constitute or imply its endorsement, recommendation, or favoring by the United States Government or any agency thereof or its contractors or subcontractors.

Printed in the United States of America. To obtain copies of this document, contact: WHC/BCS Document Control Services, P.0. Box 1970, Mailstop H6-08, Richland WA 99352, Phone (509) 372-2420; Fax (509) 376-4989.

$\frac{\text { Lamer Lachal } 1-21-98}{\text { Date }}$

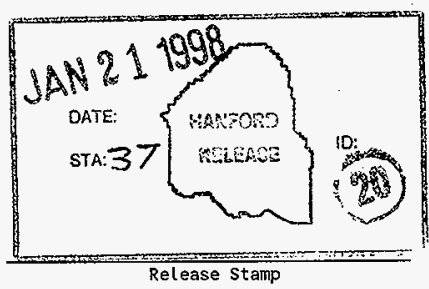


Page 2

HNF-SD-WM-TP-536

Rev. 0

\section{TESTING TO EXPAND THE ROTARY-MODE CORE SAMPLING SYSTEM OPERATING ENVELOPE}

January, 1998

Keith S. Witwer

Engineering Testing Laboratory

Numatec Hanford Corporation, Richland, WA 99352

U.S. Department of Energy Contract 80232764-9-K005 


\section{TABLE OF CONTENTS}



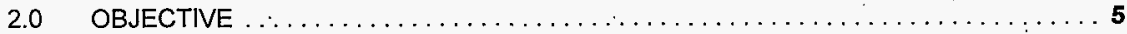

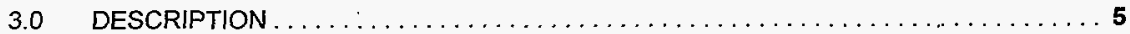

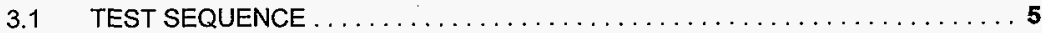

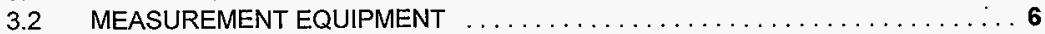

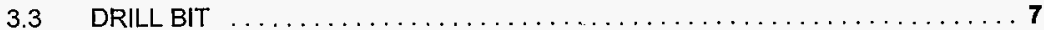

3.4 CORE DRILLING MACHINE $\ldots \ldots \ldots \ldots \ldots \ldots \ldots \ldots \ldots \ldots \ldots \ldots$

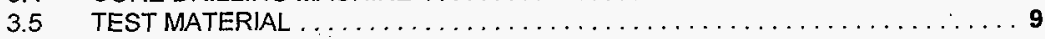

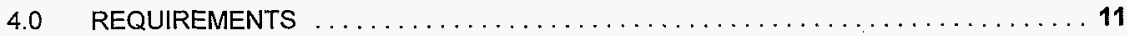

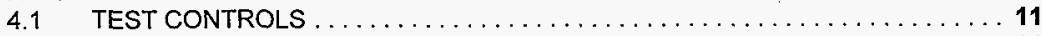

4.2 RETEST REQUIREMENTS $\ldots \ldots \ldots \ldots \ldots \ldots \ldots \ldots \ldots \ldots \ldots \ldots \ldots \ldots \ldots \ldots$

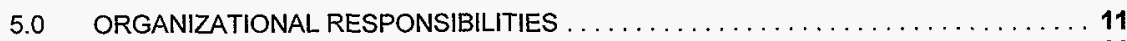

5.1 CUSTOMER ........................... 11

5.2 ENGINEERING TESTING LABORATORY .................. 12

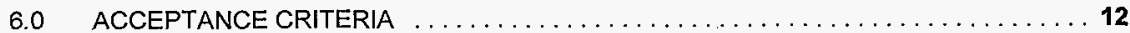

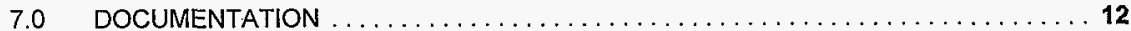

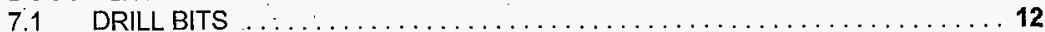

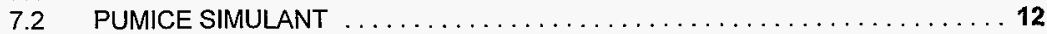

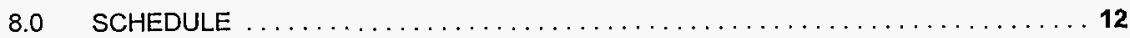

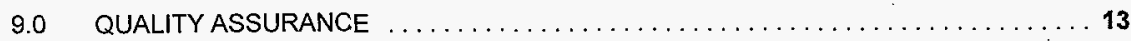

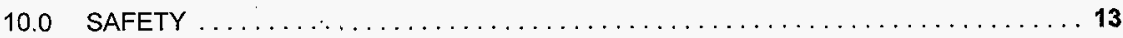

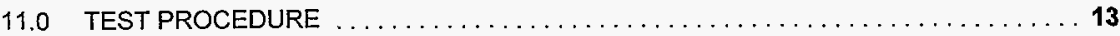

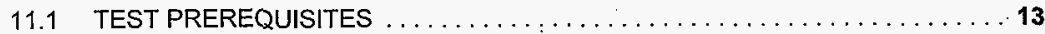

11.2 MODIFICATIONS TO TEST PROCEDURE $\ldots \ldots \ldots \ldots \ldots \ldots \ldots \ldots \ldots, 13$

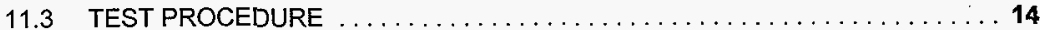

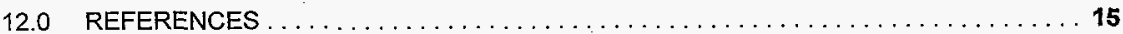

APPENDIX A - MEASUREMENT AND EQUIPMENT DATA SHEET $\ldots \ldots \ldots \ldots \ldots \ldots \ldots$

APPENDIX B - TEST DATA SHEET . . . . . . . . . . . . . . . . . . 17

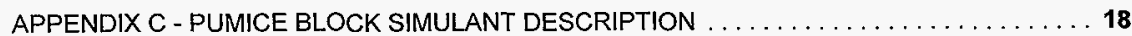


Page 4

HNF-SD-WM-TP-536

Rev. 0

\section{LIST OF FIGURES}

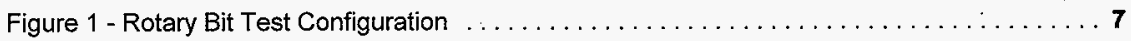

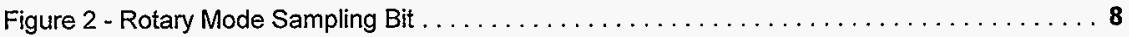

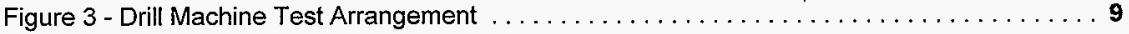

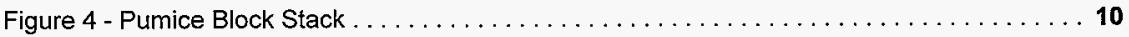

Figure 5 - Inductively Coupled Torque Sensor $\ldots \ldots \ldots \ldots \ldots \ldots \ldots \ldots \ldots \ldots \ldots \ldots \ldots$ 


\section{TESTING TO EXPAND THE ROTARY-MODE CORE SAMPLING SYSTEM OPERATING ENVELOPE}

\section{$1.0 \quad$ INTRODUCTION}

Rotary sampling using the Rotary Mode Core Sampling System (RMCSS) is constrained by what is referred to as the "Operating Envelope". The Operating Envelope defines the maximum downward force, maximum rotational speed and minimum purge gas flow allowed during operation of the RMCSS. The original values of $1170 \mathrm{lb}$. down force, $55 \mathrm{RPM}$ rotational speed, and 30 SCFM nitrogen purge gas were determined during original envelope testing (Keller, 1993). This envelope was determined by observing the temperature rise on the bit face while drilling into waste simulants. The maximum temperature in single-shell tanks (SSTs) is considered to be approximately $90^{\circ} \mathrm{C}$ and the critical drill bit temperature, which is the temperature at which an exothermic reaction could be initiated in the tank waste, was previously determined to be $150^{\circ} \mathrm{C}$ (Waste Tank Safety Analysis Team, 1996). Thus, the drill bit temperature increase was limited to $60^{\circ} \mathrm{C}$.

Thermal properties of these simulants approximated typical properties of waste tank saltcake. Later, more detailed envelope testing (Ralston and Witwer, 1996) which used a pumice block simulant, showed a notably higher temperature rise while.drilling. This pumice material, which simulated a "worst case" foreign object embedded in the waste, has lower thermal conductivity and lower thermal diffusivity than earlier simulants. These properties caused a slower heat transfer in the pumice than in the previous simulants and consequently a higher temperature rise. The maximum downward force was subsequently reduced to $750 \mathrm{lb}$ (at a maximum $55 \mathrm{RPM}$ and minimum 30 SCFM purge gas flow ) which was the maximum value at which the drill bit could be operated and still remain below the $60^{\circ} \mathrm{C}$ temperature rise.

\subsection{OBJECTIVE}

Some waste forms found in the Hanford waste tanks are difficult to sample and the new down force limit has prevented them from being sampled as effectively as they might be. It is proposed that the down force, rotational speed, and purge flow limits identified in the Operating Envelope be expanded by identifying, via testing, other down force/rotational speed/purge flow combinations which still keep the drill bit temperature rise below the $60^{\circ} \mathrm{C}$ maximum within $11 / 2$ minutes after drill bit penetration has ceased.

\subsection{DESCRIPTION}

The rotary mode bit currently used will be tested at the Engineering Testing Laboratory $(E T L)$ on a pumice block material identical to that used in the previous envelope testing (Ralston and Witwer, 1996). Thermal conductivity tests on a representative sample will be done to verify similarity with previous pumice block material. Rationale for using pumice block is described in Appendix C:

\subsection{TEST SEQUENCE}

Test combinations using downward forces of 3336 Newtons (750 lbf.) and greater, rotational speeds of 1.05 radians per second (10 RPM) and greater, and purge flow rates of 566, 850, 1133 liters per minute $(20,30$ and 40 SCFM) will be tested on the pumice block. Although initial testing 
will be of a scoping nature and exact force/rotational speed/purge flow values cannot be precisely predicted, the following test values in varying combinations are projected.

\begin{tabular}{lc} 
Down force N / (lbs) & Rotation Rate rad/s / (RPM) \\
\hline $3336(750)$ & $1.05(10)$ \\
$4448(1000)$ & $2.62(25)$ \\
$5560(1250)$ & $4.71(45)$ \\
$6005(1350)$ & $6.81(65)$
\end{tabular}

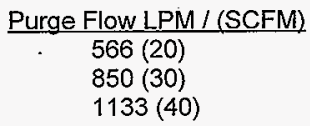

A maximum downward force of 3336 Newtons $(750 \mathrm{lbs})$, maximum rotational speed of 5.76 $\mathrm{rad} / \mathrm{s}(55 \mathrm{rpm})$, and minimum purge flow rate of 850 LPM (30 SCFM) are the current limiting Operating Envelope values. Therefore, initial tests will involve combinations with greater values for down force and speed and a lesser value for purge flow. A process of varying these parameters while staying below the $60^{\circ} \mathrm{C}$ temperature rise will continue until a combination is found that exceeds the $60^{\circ} \mathrm{C}$ temperature rise (the boundary condition). This methodology will be repeated until upper boundary conditions are identified for each of the variables. The final result of testing will be a matrix of down force/rpm/flow combinations which stay within the $60^{\circ} \mathrm{C}$ temperature rise within $1 \frac{1}{2}$ minutes after the drill bit stops penetrating. These acceptable combinations will be repeated for a total of three runs each to provide a reasonable confidence of the test results.

Discussion with drilling operators both on the Hanford site and in commerciai operations have revealed that down force appears to have a greater impact on drilling effectiveness than does rotational speed. Thus the first parameter to increase will be down force with a corresponding decrease of rotational speed as needed. Purge flow provides bit cooling and waste cutting ("fines") removal but also disrupts the core sample being obtained. In shallow waste the cuttings have a shorter distance to travel before being expelled from the core hole. A flow rate lower than the previously determined minimum 30 SCFM (Keller, 1993) could conceivably be used. A lower purge flow rate would improve sample recovery. Although a lower purge flow rate will cause the bit to heat up faster, this testing will determine what acceptable combinations can be used. Higher than 30 SCFM flow rates will be tested to show if adequate cooling can be provided at higher down force/rpm combinations. This higher purge flow could be of benefit when sampling hard waste forms which require higher down forces for penetration, but are less disrupted by high purge flow rates. Verification of performance of the core bit and core barrel relative to removal of cuttings is not part of the scope of this testing. Notation of material buildup or bit plugging, if any, will be noted in the comment section of the Test Data Sheets and/or in the controlled log book.

\subsection{MEASUREMENT EQUIPMENT}

Pertinent measurement equipment shall have current calibration and associated documentation. This equipment includes the following:
A. Purge flow pressure sensor
B. Purge flow rate sensor
C. Down force platform scale

Other equipment shall be calibrated or characterized using secondary calibration sources in the ETL. These are:
D. Type K SS Sheathed Thermocouple
E. Bit Depth Sensor 
Rev. 0

\section{F. Rotational speed sensor \\ G. Wireless Torque Sensing Device}

The bit depth measurement will be verified using a ruler with markings to $1 / 16 "$. The rotation rate sensor will be verified using a visual marker and a stopwatch with 1 second resolution. The wireless torque sensor will be verified at several applied torque values using a calibrated torque wrench with at least $+/-2$ lbs resolution. The thermocouples will be subjected to boiling and stirred freezing water baths to characterize their performance. The results from each in-house calibration/characterization shall be recorded in the controlled log book.

\subsection{DRILL BIT}

The drill bit, P.N. 1001VD/8, will be instrumented with a type K thermocouple placed directly behind one of the teeth on the inner-most row. This location has been shown (Ralston and Witwer, 1996) to be the hottest spot on the bit and the $1.6 \mathrm{~mm}$ diameter thermocouple will provide a fast indication of maximum temperatures reached. The thermocouple tip will be silver soldered approximately $6.4 \mathrm{~mm}$ below the point of the tooth. The thermocouple extension wire will be routed up through the drill string, through an electrical slip ring and continue to the data acquisition system. Figure 1 shows a cutaway drawing of the rotary bit test configuration and Figure 2 shows a photo of the rotary bit.

\section{Figure 1 - Rotary Bit Test Configuration}




Figure 2 - Rotary Mode Sampling Bit

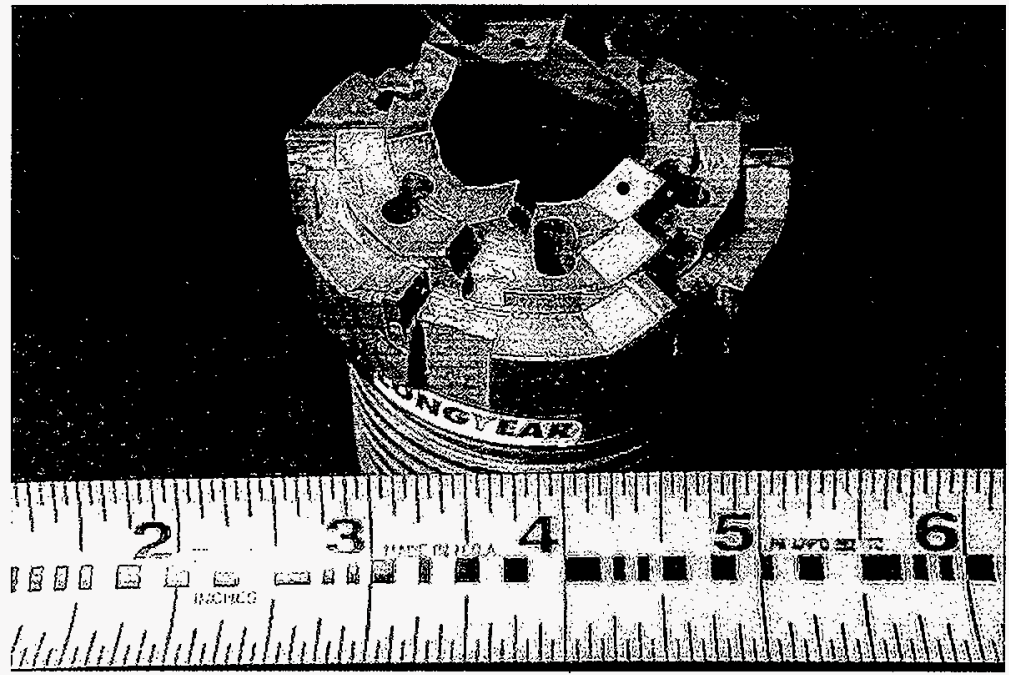

A tube of the same inner diameter as the sample hole will be placed inside the drill string in place of a rotary sampler. The tube is capped at the end farthest from the bit. The tube will seal against the bit allowing no purge gas through the sample hole while still allowing the short pumice cores to be retrieved. Closing off the sample hole was shown (Ralston and Witwer, 1996) to yield higher temperatures than with the hole open and will thus yield more conservative results. In field sampling, the current sampler/bit design has a purge gas leak path into the sample hole but the hole could be plugged by a sample core and would prevent purge gas flow through it. The outside diameter of the tube is small enough to allow the thermocouple wires to pass unobstructed through the drill string.

The thermocouples shall be characterized after installation in the drill bits to verify no damage was done as a result of silver soldering.

\subsection{CORE DRILLING MACHINE}

The Longyear Model 34 (ID \# HO-22-5272) core drilling machine will be used for testing. This machine is a test unit similar in operation to the field core sampling machines. Downward force and rotational speed can be independently controlled. Rotational speed will be measured using a magnetic sensor mounted adjacent to a toothed gear attached to the rotating shaft and is adjusted via engine speed control. Downward force is varied using a pressure valve positioned in the hydraulic line between the hydraulic pump and the upper hydraulic rams and is measured using a large platform scale placed under the simulant and drill bit. The vertical position of the bit is monitored using a linear string potentiometer attached to the hydraulic rams and the drill frame. 




Each of the above sensors has an electronic output and feeds a data acquisition unit which will display and record results during testing. Pertinent data on each sensor is listed in Appendix B.

Although Nitrogen is used for the purge gas in normal field sampling, air will be used for this testing for convenience. The thermodynamic properties of the gasses are almost identical such that substitution will have no measurable effect on the test results. Figure 3 shows the core drilling test configuration.

\subsection{TEST MATERIAL}

Pumice block, like that used in previous testing, will be used here. Figure 4 shows a typical stacked configuration of the blocks. A similar configuration will be used in this testing except that 


\section{Page 10 \\ HNF-SD-WM-TP-536}

Rev. 0

the thermocouples embedded in the block (as seen in Figure 4) will not be used. See Appendix C for a description of this test material. The pumice block will be placed on the platform scale which will provide a real-time indication of the applied downward force during drilling.

Figure 4 - Pumice Block Stack

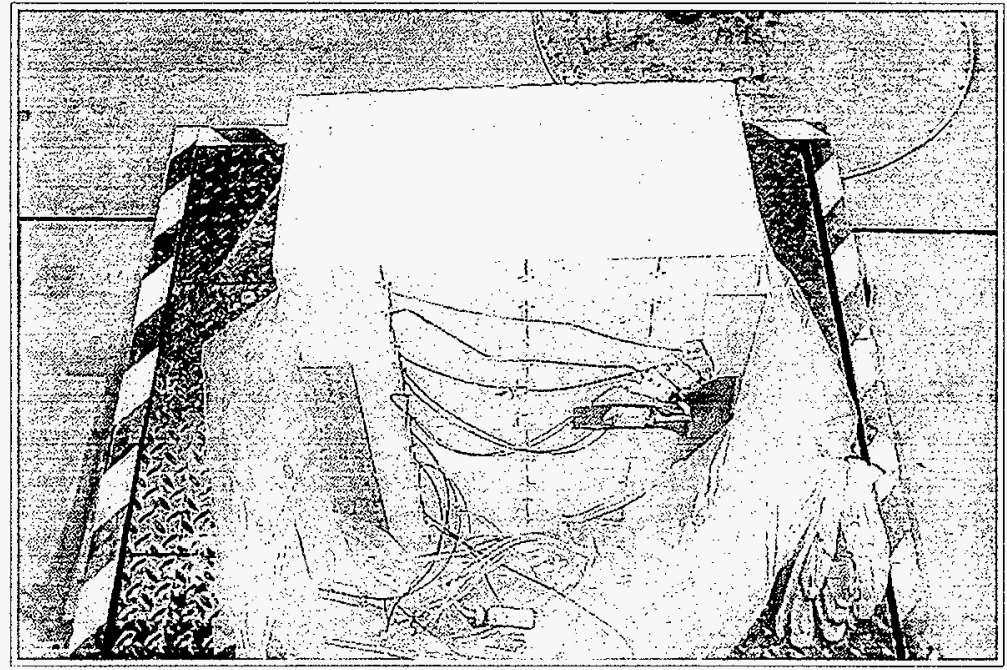

\subsection{Wireless Torque Sensing Device}

This device transmits torque values developed in the drill string during testing back to the data acquisition system.via an inductively coupled coil which surrounds the drill string. The torque is sensed using strain gages mounted on the drill string and will be compared against temperature values obtained with torque/temperature values obtained in earlier testing (Ralston \& Witwer, 1996). This will provide some additional verification and repeatability of test results. A photo of the sensor mounted on the drill string is shown in Figure 5. 
Figure 5 - Inductively Coupled Torque Sensor

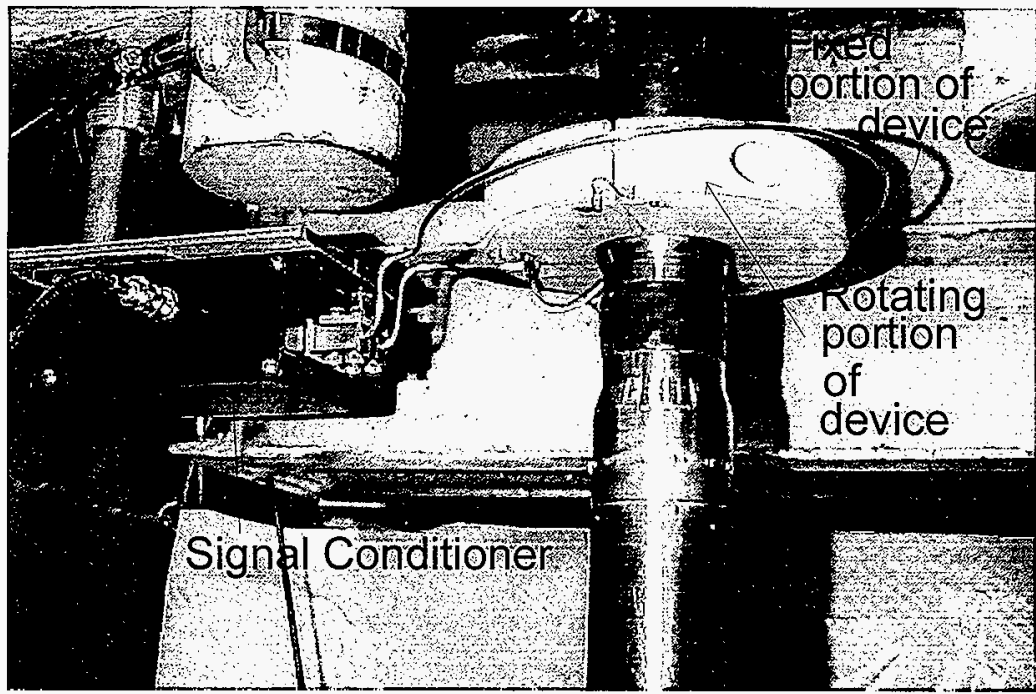

\subsection{REQUIREMENTS}

\subsection{TEST CONTROLS}

This test shall be conducted under the guidelines set forth in this document. The Test Procedure section shall define the test order. The test order may be changed by the test director as long as the change does not affect equipment, facility or personnel safety.

\subsection{RETEST REQUIREMENTS}

Any portion of the test may be re-run or re-started. However, no previously recorded data shall be destroyed and all data shall be included in the test report. All deviations from the test procedure will be noted in the Test Log. Additionally, it shall be the goal of this test plan to proceed sequentially through the test procedure. All activities for retest shall be at the approval of the test director.

\subsection{CUSTOMER}


Page 12

HNF-SD-WM-TP-536

Rev. 0

The customer for this test is the Lockheed Martin Hanford (LMH) Characterization Engineering Group (CE). CE shalt provide funding as well as any necessary sampling equipment needed for the testing.

\subsection{ENGINEERING TESTING LABORATORY}

The Engineering Testing Laboratory. (ETL), managed by Numatec Hanford Company, will be responsible for testing. This includes the generation of the test plan/procedure and test report, performance of the test, and interface with Characterization Project (CP) management, engineering and technical personnel as needed.

\subsection{ACCEPTANCE CRITERIA}

Expansion of the Operating Envelope will be supported by a documented increase of either the existing down force and/or rotational speed and/or purge gas flow rate while still staying below the $60^{\circ} \mathrm{C}$ temperature rise within $11 / 2$ minutes after the drill bit stops penetrating. This criteria must be met by each repeat run (in any particular test combination) to be considered valid.

\subsection{DOCUMENTATION}

Any notes or exceptions to the test plan will be documented in the controlled logbook, HNF$\mathrm{N}$-23. In addition, a test data sheet (Appendix B) will be used for each test. These data sheets, along with any notes entered into the logbook, shall be included in a supporting document test report which will be prepared at the conclusion of testing. All pertinent instrument calibration reports will also be included as an appendix to the test report.

\section{7:1 DRILL BITS}

The rotary bits used for testing shall be procured with proper receipt inspection and will be controlled/maintained by the Test Director. Each bit will have a unique serial number and shall be identified by these numbers in any associated documentation.

\subsection{PUMICE SIMULANT}

The pumice block simulant will be of the same type as used in previous envelope testing. Verification of material property similarity will be documented via testing, at the Hanford $222 \mathrm{~S}$ laboratory, of the thermal conductivity of a representative sample. This conductivity value will be within $+1-5 \%$ of the conductivity value obtained from the previous pumice block sample, and a will be included as an appendix in the final test report. A description of the simulant selection is found in Appendix C.

\subsection{SCHEDULE}

Test duration is expected to be approximately four weeks followed by a supporting document test report ready for review two to three weeks later. 


\subsection{QUALITY ASSURANCE}

Quality Assurance will review the documentation associated with this testing as part of the review process. Quality Control (QC) will witness and/or verify the setup of the test procedure.

\subsection{SAFETY}

Only trained, qualified personnel are authorized to operate the RMCS test equipment. The test director will be responsible for insuring appropriate qualification training.

Site safety personnel will review the test plan and procedure as part of the review process. A facility Job Hazard Analysis will also be generated by the test director, or his designee, which will identify hazards associated with the testing. A pre-job meeting will be conducted by the Test

Director and shall include, as a minimum, any personnel directly involved with the hands-on testing.

\subsection{TEST PROCEDURE}

\subsection{TEST PREREQUISITES}

Prior to the initiation of testing the following conditions shall be verified:

1. The test apparatus has been configured, leak checked, loop calibrated, and initially verified operational.

Verified

Test Director
Verified

Date QC Representative
Date

2. The information for all instruments shown in Appendix $A$ and all associated calibration documentation has been verified.

Verified

Test Director
Verified

QC Representative Date

\subsection{MODIFICATIONS TO TEST PROCEDURE}

Minor changes to the Test Procedure can be made at the discretion of the Test Director. Changes to the scope of testing or major procedural changes shall only be made with prior approval of the CP Design Authority.

If any steps in this section cannot be performed as required or results in an abnormal condition, a log entry identifying the problem will be made. The resolution of the exception will determine what testing, if any will need to be repeated.

The testing may be halted at any time by any test personnel when an unsafe condition exists that could harm the facility, equipment or personnel. 
Page 14

HNF-SD-WM-TP-536

Rev. 0

\subsection{TEST PROCEDURE}

Ensure all necessary core driling and test equipment has been functionally checked. Prepare log sheet specific to pending test.

1. Place bit against pumice block and engage down force control. Set maximum down force to the desired value. (Section 3.1). Raise drill string.

II. Adjust purge flow to 30 SCFM through the bit. Gas temperature and pressure must be taken into consideration when obtaining this value.

III. Set engine speed and gear position so that drill rotates at the desired RPM. Stop rotation and position the tip of the drill bit so that it is just resting on the pumice block surface. Mark this depth as point "Zero" in the data acquisition system.

IV. Place cover over simulant container and attach vacuum to catch dust generated while drilling.

V. Start Data Acquisition System (DAS) recording with unique test file name at 5 second intervals.

VI. Engage bit rotation and downward travel control.

VII. Monitor bit penetration. Once penetration stops (due to bit wear) allow test to continue for $11 / 2$ to 2 more minutes.

VIII. Raise drill bit and stop rotation.

IX. Stop DAS recording and shut off drill machine. Enter pertinent data on Test Data. Sheet.

X. Remove worn drill bit and replace with a new instrumented drill bit. Start new test at step I.

Note: Some additional information concerning the operation of the drill rig will be covered in a prejob meeting given by the test director. 
Page 15

HNF-SD-WM-TP-536

Rev. 0

\subsection{REFERENCES}

Keller, C. M., 1993, "Core Drill Operating Envelope Test Report", WHC-SD-WM-TRP-123, REV. 1, Westinghouse Hanford Company, Richland, Washington.

Ralston, G. L., and K. S. Witwer, 1996, "Standard Rotary Bit Temperature Testing Supporting the Safety Assessment for Rotary Mode Core Sampling in Flammable Gas Tanks", WHC-SDWM-TRP-252, REV. 0, Westinghouse Hanford Company, Richland, Washington.

Waste Tank Safety Analysis Team, 1996, "A Safety Assessment of Push-Mode and Rotary Mode in Flammable Gas Single Shell Tanks", WHC-SD-WM-SAD-035, REV. 0, Los Alamos National Laboratory, Los Alamos, New Mexico. 
Page 16

HNF-SD-WM-TP-536

Rev. 0

\section{APPENDIX A - MEASUREMENT AND EQUIPMENT DATA SHEET}

\section{Equipment Calibration Data}

\begin{tabular}{|c|c|c|c|}
\hline ttem & Hanfordstol Lab & RangefAccuracy & Caltexpiration \\
\hline $\begin{array}{c}\text { Omega CL505A Temperature } \\
\text { Calibrator }\end{array}$ & $750-13-55-002$ & $+1-0.5^{\circ} \mathrm{C}$ & $7 / 22 / 98$ \\
\hline Celesco PT101-40A & ETL Lab Cal & 24" +/- 1/16" & Cal/Accur chk as reqd \\
\hline Toledo/Mett Mdl 8140 & $750-66-01-004$ & $0-2000 \mathrm{lb}(\mathrm{Cal}) \pm 2 \mathrm{lb}$ & $12 / 21 / 98$ \\
\hline Cole-Parmer Flowmeter & N/A & 4-50 SCFM +/- 1 SCFM & - \\
\hline Type K TC & ĖTL Lab Cal & $0-300^{\circ} \mathrm{C} / \pm 2^{\circ} \mathrm{C}$ & - \\
\hline Pressure Gage & TBD & $+/-1$ PSI & TBD \\
\hline $\begin{array}{l}\text { SnapOn } \\
\text { Torque Wrench (Electronic) }\end{array}$ & $750-88-01-005$ & $15-250 \mathrm{ft}-\mathrm{lb} / \pm 1 \mathrm{ft}-\mathrm{lb}$ & $3 / 20 / 98$ \\
\hline
\end{tabular}


Page 17

HNF-SD-WM-TP-536

Rev. 0

APPENDIX B - TEST DATA SHEET

RMCSS OPERATING ENVELOPE EXPANSION

TEST DATA SHEET

D.A.S. TEST ID. NO.

DRILL BIT SERIAL NUMBER

DRILL BIT THERMOCOUPLE SERIAL NUMBER

ROTATIONAL SPEED:

(RPM)

DOWNWARD FORCE:

$\left(\mathrm{Ib}_{\mathrm{f}}\right)$

PURGE GAS FLOW RATE:

MAXIMUM DRILL. BIT TEMPERATURE REACHED

TEST DURATION

COMMENTS:
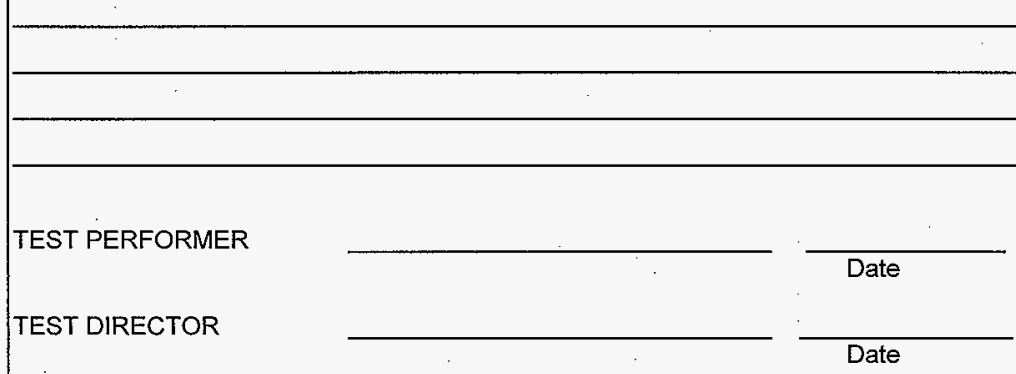
Page 18

HNF-SD-WM-TP-536

Rev. 0

\section{APPENDIX C - PUMICE BLOCK SIMULANT DESCRIPTION}

Much of the following information is taken from WHC-SD-WM-SAD-035, A Safety Assessment of Push-Mode and Rotary-Mode in Flammable Gas Single Shell Tanks, Appendix F.

Table 1 compares properties of the pumice material to the properties of the waste simulant materials developed during testing by (Keller, 1993).

TABLE 1 - COMPARISON OF WASTE SIMULANT AND PUMMICE TEST MATERIAL

\begin{tabular}{|l|c|c|c|}
\hline \multicolumn{1}{|c|}{ Property } & $\begin{array}{c}\text { Evaporator } \\
\text { Bottoms }\end{array}$ & $\begin{array}{c}\text { BY-104 } \\
\text { Simulant }\end{array}$ & $\begin{array}{c}\text { Pumice } \\
\text { Block }\end{array}$ \\
\hline Bulk Density $\left(\mathrm{kg} / \mathrm{m}^{3}\right)$ & 1560 & 1410 & 1600 \\
\hline Unconfined compressive strength (psi) & 905 & 3,264 & \\
\hline $\begin{array}{l}\text { Calculated compressive strength from } \\
\text { drilling tests }(\mathrm{psi})\end{array}$ & & & 10,000 \\
\hline Direct shear strength $(\mathrm{psi})$ & & 459 & \\
\hline Penetrometer resistance $(\mathrm{psi})$ & 23,520 & 34,507 & \\
\hline Thermal conductivity $\left(\mathrm{W} / \mathrm{m}^{*} \mathrm{~K}\right)$ & 2.32 & 1.67 & 1.03 \\
\hline Spècific heat $\left(\mathrm{kJ} / \mathrm{kg}^{*} \mathrm{~K}\right)$ & & $0.97^{*}$ & $0.88^{* *}$ \\
\hline Thermal diffusivity $\left(\mathrm{m}^{2} / \mathrm{s}\right)$ & & $1.221 \times 10^{-6}$ & $7.315 \times 10^{-7}$ \\
\hline Volumetric Heat Capacity $\left(\mathrm{J} / \mathrm{m}^{3 *} \mathrm{~K}\right)$ & & 1368 & 1408 \\
\hline
\end{tabular}

* Estimate based on handbook value for predominate material.

** Handbook value

The physical and thermal properties are comparable for pumice and BY-104 simulant. The density times the specific heat products for the BY-104 simulant and the pumice block are within three percent of each other. Thus, the energy storage terms (volumefric heat capacity) are very comparable. The lower thermal diffusivity coefficient of the pumice block tends to slow the spread of heat and keep temperatures higher. Thus, testing with pumice block will produce temperatures that are conservative compared to BY-104 simulant, and envelope testing (Keller, 1993) identified the BY-104 simulant as the limiting waste simulant. 


\section{DISTRIBUTION SHEET}

\begin{tabular}{|c|c|c|c|c|c|c|}
\hline \multirow{2}{*}{$\begin{array}{l}\text { To } \\
\text { Distribution }\end{array}$} & \multirow{2}{*}{\multicolumn{4}{|c|}{$\begin{array}{l}\text { From } \\
\text { K.S. Witwer }\end{array}$}} & \multicolumn{2}{|l|}{ Page 1 of 1} \\
\hline & & & & & \multicolumn{2}{|c|}{ Date $1 / 20 / 98$} \\
\hline \multirow{2}{*}{\multicolumn{5}{|c|}{$\begin{array}{l}\text { Project Title/Work Order } \\
\text { HNF-SD-WM-TP-536, Rev. O } \\
\text { Testing To Expand The Rotary-Mode Core Sampling System Operating } \\
\text { Envelope }\end{array}$}} & \multicolumn{2}{|c|}{ EDT No. 601048} \\
\hline & & & & & \multicolumn{2}{|l|}{ ECN No. $\quad N / A$} \\
\hline Name & & MSIN & $\begin{array}{l}\text { Text } \\
\text { With All } \\
\text { Attach. }\end{array}$ & Text Only & $\begin{array}{l}\text { Attach./ } \\
\text { Appendix } \\
\text { Only }\end{array}$ & $\begin{array}{c}\text { EDT/ECN } \\
\text { Only }\end{array}$ \\
\hline R. M. Boger & & $57-12$ & $x$ & & & \\
\hline J. D. Criddle & & $57-12$ & $x$ & & & \\
\hline R. N. Dale & & $57-12$ & $x$ & & & \\
\hline C. E. Hanson. & & $57-12$ & $x$ & & & \\
\hline G. P. Janicek & & $57-12$ & $x$ & & & \\
\hline A. J. Kostelnik & . & $S 7-12$ & $x$ & & & \\
\hline J. S. Schofield & & $57-12$ & $x$ & & & \\
\hline J. L. Smalley & & $57-12$ & $x$ & & & \\
\hline K. S. Witwer (2) & & $16-13$ & $x$ & & & \\
\hline Central Files & & BT -07 & $x$ & & & \\
\hline
\end{tabular}

